\title{
FROM THE PROJECTION OF HUMAN ORGANS TO THE PROJECTION OF AN ARTIFICIAL MAN Current Framework of Philosophy of Technology
}

Ivana Greguric, Ivo Džinić

UDC 1Kapp, E.

$1:[572+62]$

007:179

https://doi.org/10.32701/dp.23.1.5

Original scientific paper

Received: 10.11.2021

Accepted: 30.12.2021

Abstract

Based on the thesis of Ernst Kapp about the projection of organs during the initial creation of tools, the current article tries to show that this thesis still has its implications today. Indeed, if Kapp claims that the man created tools by observing his organs and their functionality, then it should also be stated that today, from a technical point of view, the man has reached the position of projecting technically sophisticated tools for the replacement of human organs. There is an increasing tendency of human organ replacement aiding, and in many ways facilitating, human life, but also conscious and coordinated cyborgization and robotics with the aim of accelerating and improving that same life to the level of challenging a new stage of its evolution. Thus, the current framework of the philosophy of technology emerges, which was mainly initiated by Kapp's thesis.

KEYWORDS: cyborgization, Ernst Kapp, evolution, organ, philosophy, posthumanism, projection, robotics, technique, transhumanism

\section{Introduction}

Due to the dynamics of cultural evolution and the contributions of technology in this process, one often has the impression that the close connec-

* Ivana Greguric, PhD, Assistant Professor, Faculty of Croatian Studies, University of Zagreb, Borongajska cesta 83d, 10000 Zagreb, Croatia.E-mail: igreguric@hrstud.hr

ORCID iD: https://orcid.org/0000-0002-0148-2334

* * Ivo Džinić, PhD, Associate Professor, Faculty of Croatian Studies, University of Zagreb, Borongajska cesta 83d, 10000 Zagreb, Croatia. E-mail: idzinic@hrstud.hr 
tion between a man (or humanity) and technology has almost reached its peak. Technology is omnipresent, and it is undisputed that in many respects it facilitates a decent and dignified (co-)life for the man, but also greatly expands his life horizons. A direct consequence of this is the fact that discussions about its impact on humans are becoming more and more typical. It is not surprising, however, that the outlines of philosophical reflection in the field of technology appeared quite early, at least when compared to today's standards. Already at the end of the 19th century, German philosopher and geographer Ernst Kapp (1808-1896) ${ }^{1}$ dealt with this close connection between the man and technology and began a philosophical reflection that essentially continues to this day, that is, this reflection on the influence of technology on human life has not yet been fully exhausted.

His work, Basic Lines of the Philosophy of Technology. On the History of the Origin of Culture from New Points of View, ${ }^{2}$ is considered a pioneering work in the area of philosophical reflection. The title of the work states that the author is concerned with understanding technology within culture as its broader context and in connection with the man as the producer and product of that very culture. ${ }^{3}$ However, starting from the man and his idea of creating technical tools by observing his own body and organs, Kapp also points out the reversibility of this process, i.e., its repercussion on the man. Founded on the work and the presentation of the basic ideas of the thesis of organ projection, here we will examine the further possible implications of Kapp's philosophy on contemporary discussions about technology and, in particular, its impact on the man. The latter is today able to project a technically sophisticated replacement of human organs, which means, among other things, that there has been a kind of process change and reversibility of organ projection in Kapp's sense. It is a planned, coordinated, and desired improvement of the human organism, i.e., the cyborgization of it, often in

1 Ernst Christian Kapp was born in the Bavarian town of Ludwigstadt in Germany. He studied classical philology in Bonn and received his doctorate in history. In the mid-19th century, he emigrated to the United States, where he soon became socio-politically active. Kapp returned to Germany in 1865 and worked as a private assistant professor in Düsseldorf, where in 1877 he wrote his Fundamentals of the Philosophy of Technology. On the History of the Emergence of Culture from New Points of View (Grundlinien einer Philosophie der Technik. Zur Entstehungsgeschichte der Kultur aus neuen Gesichtspunkten). He died in that city in 1896.

2 Ernst Christian Kapp, Grundlinien einer Philosophie der Technik. Zur Entstehungsgeschichte der Cultur aus neuen Gesichtspunkten (Braunschweig: George Westermann, 1877).

3 Kapp himself clearly points this out when he writes the following: "Here is the real threshold of our research, namely, the man who has laid down his historical sample with the first apparatus - his work - then the historical man in general, who is in the process of self-knowledge. This is the only sure starting point for any spiritual contemplation and orientation about the world. For that which is absolutely certain for a man is actually only himself.” Kapp, Grundlinien einer Philosophie der Technik, 39. 
the belief that this is exclusively something positive and useful for the human being itself. In this sense, one can speak of a kind of closing of the circle that Kapp opened with his thesis of organ projection, and this also represents the current framework of the philosophy of technology.

\section{Basic ideas of Kapp's philosophy of technology}

\subsection{Kapp's understanding of technology}

Kapp understands technology conceptually and substantively quite broadly and as something that does not refer only to the material realm. He considers it an instrumentalization of technology if it is understood only in terms of its function and usefulness to humans. However, he also recognizes in technology something far more effective, insofar as it can contribute to human self-reflection and the development of self-awareness. Kapp already points to this in the preface to his book when he writes that he seeks to explain "the origin and perfection of the artifacts that come from the hand of man as the first condition for his development into self-consciousness ${ }^{4}$." Indeed, by looking at the technical devices in the world around him, which in many ways mirror the structure and functioning of his organism, the man reveals his own inner self in the same world. This means that Kapp is not only concerned with the aspect of creating technical devices, but also with projecting them back onto the human being to better understand his own organs and ultimately himself. Starting from the role of technology for the development of human self-consciousness, it is obvious that Kapp's entire theory of culture is based on the philosophy of technology. For him, in fact, tools are so thoroughly and intimately connected with the man that they arouse feelings of wonder when he actually observes in the creation of his hands something of his own being, of his imaginative world embodied in the matter, the reflection and imitation (Nachbild) of his own inner being. Consequently, the mechanism that unconsciously formed according to the organic modelserves at the same time as a model for clarifying and understanding the organism to which it owes its origin. Kapp already points to this important dimension of the production and improvement of technical tools as the first condition for human development in the sense of self-consciousness in the preface to his study. It follows from all this that for Kapp, the man is not a flawed being who tries to compensate for his inadequacies with technology but has a much closer connection with technology. 
In further remarks, Kapp will show that technology is at the same time a kind of instrument for regulating social and political life, which then justifies his inclusion of language and state analysis in the thesis of organ projection. Indeed, for Kapp, language is in many ways superior even to the machine, as it is what makes the full power of culture and human self-expression possible in the first place. ${ }^{5}$ The only tool that is more organic, more organized, and more reflective of human projection than language is the state. In an organization like the state, Kapp sees a complete reflection of the human organism, and he asserts in this regard, "The whole man is in the state, but the whole state is also in the man. It is true that the man is Zoon politikon, but also the state is Polisma anthropikon. The activities of the man are not carried out by the head only or by the hand only, but by the whole man. Therefore, everything that is human and emanates from him is at the same time from the state ${ }^{6}$." For Kapp, then, the state is the purest image of organ projection, the most authentic tool created for the external organization of human beings, just as the body itself is organized from within. Thus, not only individual tools but also complex technical systems such as language or the state itself can be replicas of bodily organic structures, to which Kapp devotes an extensive part of his study and which simply need not be presented further here for purely technical reasons.

\subsection{Thesis on organ projection}

The starting and central point of Kapp's philosophy of technology is the concept of organ projection, i.e., the theory that all technical artifacts can and must be seen as the result of the process of projecting one's own organs and body into the external world. As mentioned above, according to Kapp, this projection of one's own body refers not only to material elements such as tools and machines, but also to mental phenomena such as language and the state because for Kapp both the human psyche and the human spirit are the very sources of technology. ${ }^{7}$ Hence, in addition to the human body as the model upon which humans base their technical creation and development, the human spirit and psyche also play an important role. This is also why

5 Such a claim is in line with Kale's that culture is made possible by the appearance of symbols but exists and develops thanks to a special form of symbolic behavior, i.e., language or speech. Cf. Edvard Kale, Uvod u znanost o kulturi (Introduction to the Science of Culture) (Zagreb: Školska knjiga, 1982), 44.

6 Kapp, Grundlinien einer Philosophie der Technik, 310.

7 Cf. Alois Huning, "Ernst Kapp: Grundlinien einer Philosophie der Technik. Zur Entstehungsgeschichte der Cultur aus neuen Gesichtspunkten,” in: Christoph Hubig, Alois Huning, Günter Ropohl (ed.), Nachdenken über Technik. Die Klassiker der Technikphilosophie (Berlin: Edition Sigma 2013), 217. 
the process of projecting organs into the world is generally not intentional, but unconscious. Indeed, when Kapp explains the origin of technical devices, he claims that they were not created by consciously analyzing the way nature performs such a function in the human body, but that the realm of the unconscious exerts influence over it. Kapp devoted an entire chapter to this moment of the unconscious ${ }^{8}$ and returned to it again and again.

The first tools appear as an extension, consolidation and tightening of the organs of the body when one uses objects that are in proximity, or at hand, so to speak. Therefore, these tools, created in close orientation to the human organs, represent at the same time an improvement of these organs in terms of their function. For Kapp, the richness of the projections of human organs into tools and its creativity springs primarily from the human hand as the "tool of all tools" and its triple function: first as an innate tool, then its role as a model for some mechanical tools, and finally its crucial role in the production of material imitations or replicas. The book gives several examples of tools whose model is a hand, such as a hammer as a projection of the forearm and clenched fist, a hook as a replica of a curved finger as a reconstruction of a lowered hand, a index finger that with its sharpness becomes a drill, and the gripping arm (just like the jaw structure!) is the basis of imitation for pliers and the function of the vice. Moreover, according to Kapp, in the case of the sword, spear, oar, shovel, rake, plow, etc., one recognizes certain alignments of the hand, fist, and fingers, the adaptation of which can be traced for the manufacture of various tools. ${ }^{9}$

In addition to the significant role of the hand as the tool of all tools, Kapp also treats other tools as further projections of organs. ${ }^{10} \mathrm{He}$ recognizes, for example, the reflection of human teeth and nails in the blades of an axe and in the teeth of a saw. In these technical artifacts, then, the recognized body parts are sharper than normal and therefore more effective, for the tool has interacted to support the development of the natural organ. The tools become better than the organs after which they are formed, but through these tools, the man

8 This is the ninth chapter of this study, entitled "Das Unbewusste" (Unconscious), 155-164.

9 Cf. Kapp, Grundlinien einer Philosophie der Technik, 43-45. In addition to the above, the hand projected the measures that are inherent in its nature as well as their numerical values for Kappa with the tool. Thus, the hand did not influence the man only by the projection of tools, but he could also use the hand to find numbers and measures and thus contribute to the construction of cultural life. Kapp writes about this in more detail in the fourth part of his study entitled "Gliedmaassen und Maasse”, 68. et seq., Stating, inter alia, that "handicraft, action, craft, counting unit, measure and weight, number and invoice refer to the hand", 71 .

10 Kapp's thesis on the unconscious projection of human organs is based on the etymological

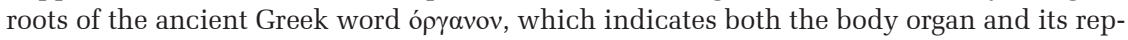
lica, i.e., the tool itself, as well as the material from which it is made. Cf. Kapp, Grundlinien einer Philosophie der Technik, 40. 
learns more about himself and his body. In this sense, tools can also be called "quasi-organs" because their form and function are based on the human body.

Kapp also sees further confirmation of his thesis of organ projection in the naming of tools. He believes that the root of naming tools is essentially related to the original organic activity, so that the word and the object in question come from a common root. ${ }^{11}$ From an etymological point of view, according to Kapp, some names of tools can be traced back to activities performed by the man himself. He further clarifies this by stating that each name is older than the activity itself and that the word existed before the man used other organs in relation to the innate natural organs. As an example of this, Kapp cites the name of the sculpture and claims that the word sculpo is a rarer form of the word scalpo and at first only referred to scratching with nails. ${ }^{12}$ The man, then, did not name the tools until after he had created them, and was thus able to receive feedback about his creation, which enabled him to name the tools as a consequence.

However, Kapp was not only concerned with tools from everyday life, he was also concerned with machines that over time reduced human involvement in a particular activity, though no machine ever completely took the human hand out of the equation. ${ }^{13}$ According to Kapp, these machines cannot be understood as projections of individual organs, but rather the projection of the entire human organism itself. In other words, the man had to unconsciously return to himself to build machines, specifically, to put the parts of the inanimate machine into appropriate functional activity according to the model of the unique living whole of the members of his bodily organism. Kapp will thus argue that the tools and instruments that the man creates with his own hands correspond to pre-existing organic structures, notwithstanding the slightest conception of how these pre-existing structures might function. ${ }^{14}$ It follows that the tool is an analogy of the organ, and that knowledge of something external is also knowledge of the internal. 
Analogous to the hand as the tool of all tools, Kapp sees the steam engine as "the machine of all machines." 15 He recognizes the parallels between the steam engine and the human food system, with both sides having the goal of generating power and thus the ultimate ability to accomplish the task. Therefore, the path to the goal itself can be briefly described as feeding, burning, and generating power. The human feeds on food and the steam engine feeds on fuel, followed by the digestion of food on the human side and combustion on the steam engine side. ${ }^{16}$ Kapp believed that the man could not make a connection between the sustenance and the generation of energy and power until he invented the steam engine and compared it to his own body. It is for this very reason that a living organism, with all its infinite variety of analyses, can be compared to a steam engine.

Concluding this section, Kapp's thesis on the projection of organs into technical tools, as well as their contribution to the development of human self-consciousness, shows that man does and represents everything he creates with his own hands. In view of the future technical possibilities of cyborgization and the development of superintelligence, which will be discussed in the following chapter, this seems to us to be exactly the opposite.

\section{Reversible forms of organ projection}

The projection of biologically human organs into cultural reality, as well as the replacement of diseased organs by scientific and technical interventions, tends towards a transhuman and posthuman future without the biological human.

Information communication technology (ICT) ${ }^{17}$ is already cyborgizing, shaping and forming cultural-historical reality, influencing human consciousness and social relations, shaping communication with the world and nature, and transforming our personhood and self-understanding. We can justifiably argue that ICT are in this way transforming the current biological anthropology and ontology of human beings, creating a new virtual and augmented reality, or "ubiquitous computing" in historical reality. The online digital world is immersing and merging with the offline world to form the life-giving infosphere. In the near future, biological humans will be oc-

16 Cf. Kapp, Grundlinien einer Philosophie der Technik, 130.

17 ICT is an acronym for "information communications technology." It refers to technologies that provide access to information through telecommunications and focuses on communication technologies. This includes the Internet, wireless networks, mobile phones and other means of communication. 
cupied by ICT entities that will function independently of their agency and tend to function without their command.

Cyborgization views the human body and mind as a cyborg organism composed of information that enables science and technology to more completely and accurately model, simulate, and manage the human body and mind invasively and non-invasively. It is undeniable that cyborgization in medicine enables the return of the damaged part of the body and mind to the limits of biological functioning. Today it is possible to replace almost all biological organs with technical organs, except for the brain. However, scientists promise that this, too, will be possible soon.

When we speak of the cyborgization of a healthy human body and mind, we are talking about the scientific-technical enhancement and transformation of the man according to the transhumanist visions of the continuation of human evolution in the scientific history. The advancement of the hacking of the human body and mind is in the direction of physical, cognitive, and emotional improvement through the incorporation of various technological inserts that are available over the counter without legal or ethical restrictions. In this way, such a human enhancement perspective and modifications of the biological basis of human beings is left to the individual's freedom of choice to co-create evolutionary processes and take control over their own lives.

Transhumanism strives to transcend the natural in humans and thus transcend the human in the name of scientific and technological creationism. This philosophy and practice hold the ontological and anthropological possibility of the inhuman and the unnatural, because in the depths of technology, understood as a means of humanization and progress, its true metaphysical essence is hidden.

The contradictory position of the man in the absolute world of science and technology makes him the subject of the whole historical movement on the one hand, and on the other hand, the man is the moment and object of scientific and technological development in his ontological self-development, in which every object is rationally placed in to what it is. This position of co-action through Absolute ${ }^{18}$ gives the man the possibility of absolute and limitless power in the eternal present. However, as the moment and object of the self-movement of the Absolute, a human being is also powerless because he has no human essence, but it arises from the struggle as an illusion. Man's power is the impotence of his struggle, which sets the world into nothingness. The transhumanist aspiration of the man as a self-conscious subject for the enhancement and reshaping of his own body and mind re- 
flects the desire of the modern man to ensure live longer and healthier lives through the use of technology. This includes placing the man on a new scientific and technical basis.

Posthuman is an adjective that refers to what is after death, something posthumous. Who has died and what is hidden in the content of the term behind the death of humanism and naturalism? Who or what exists after them? From the knowledge of the transhuman essence of technology in the scientific history, which in setting up everything that is in discovery conceals its transhuman and posthuman essence, we can conclude that behind the natural and transhuman life of the man and his biological death comes an artificial life that will take over the human intelligence. Life in and outside the computer in virtual reality and robots with superintelligence in the historical reality of scientific humanism are what exists behind the posthuman.

Turing's ideas have led many scientists to develop superintelligence. Marvin Minsky, for example, an American cognitive scientist in the field of artificial intelligence, takes a step back and refers to the human brain as the "machine flesh"19 and the body as a "bloody mess of organic matter." 20 This practically implies the rejection of the biological and its replacement by a machine, i.e., a scientific-technical form of life. This transition from the "machine flesh" and the "bloody mess of organic things" we call mind and body will inspire the path of transition from the natural-human to the artificial-created. Bostrom wonders, "Will there be one super intelligent power or many? Might an intelligence explosion propel one project so far ahead of all others as to make it able to dictate the future? Or will progress be more uniform, unfurling across a wide front, with many projects participating but none securing an overwhelming and permanent lead?"21

We wonder what a world order would look like in which a single active computer mind (independent or directed by someone) makes strategic decisions about the future of the world and humanity. This possibility of superintelligence self-development opens up new ontological, ethical, political, and economic questions related to the survival of the world and Earth. According to some estimates, humans have appropriated "only $24 \%$ of the planetary ecosystem's net primary production. And yet we are far from having reached the physical limits of technology. Such entities could accumulate content much faster than us and invent new technologies on a much

McCorduck, Pamela. Machines Who Think: A Personal Inquiry into the History and Prospects of Artificial Intelligence (San Francisco: W. H. Freeman, 1979), 101.

20 Turkle, Sherry. The Second Self, Twentieth Anniversary Edition. Computers and the Human Spirit (Cambridge-Massachussets-London: MIT Press, 2005).

21 Bostrom, Nick. Superintelligence - Paths, Dangers, Strategies. United Kingdom: Oxford University Press. 2014. 78 
shorter timescale. They could also use their intelligence to strategize more effectively than we can." 22

The owners of artificial intelligence projects (investors, militaries, governments, scientists) have the potential to gain great power. The one who controls the first superintelligence has a strategic advantage. However, Bostrom believes that the superintelligence can oppose the project and seize all power, resulting in a superpower that can no longer be controlled by the project owners. With it superpower of strategic behavior, it can develop a plan to achieve its long-term goals. It can also use its superpower of hacking to escape the project, not only in the apparent world but also in the analog world. For example, by hacking, it can take direct control of robots, automated machines, and labs, eliminating humans from the development and control process. This means that there is a possibility that the superintelligence could endanger all life originating from Earth. In perspective, it might be able to "form a singleton and to shape the future of Earth-originating intelligent life. What happens from that point onward would depend on the superintelligence's motivations." ${ }^{23}$

The self-evolution of the countless replicants means that they will have to gather an infinite number of resources, and one of these resources will certainly be humans. "If we now reflect that human beings consist of useful resources (such as conveniently located atoms) and that we depend for our survival and flourishing on many more local resources, we can see that the outcome could easily be one in which humanity quickly becomes extinct." 24 Despite the dangers of developing superintelligence, the outcome is certainly preordained: "Too much has been invested to pull back now. AI researchers have been working to get to human-level artificial general intelligence for the better part of a century: of course there is no real prospect that they will now suddenly stop and throw away all this effort just when it finally is about to bear fruit." 25

\section{Conclusion}

In a relatively short time, humanity has moved from the projection of organs into cultural reality, as Kapp thought, to the transhuman scientific-technical projection of man into virtual reality and "ubiquitous computing", and finally to posthuman scientific-technical forms of robotic existence and artificial 
intelligence. By projecting his organs and building the world around him, the man simultaneously contributes to himself and his own self-consciousness by revealing his inner self. Through the work of his hands, he made life easier for himself and came to know himself. Today, this initial development of technology has progressed to the point where technically sophisticated tools can be used to replace human organs. This certainly makes human life easier in many ways, but it also raises several questions about the appropriate limits and end results of further deliberate and coordinated cyborgization and robotics. It is precisely this journey that we have taken from the projection of our own organs into cultural reality to the contemporary projection of the artificial human as the current framework of the philosophy of technology, with, of course, its anthropological dimension foremost in mind.

In any case, philosophy and ethics, as well as humanity as a whole, face the task of adopting thoughtful ethical principles about the limits of transhuman enhancement of human beings and the existence of posthuman beings. The principles must start from the meaningful value of life, which is older than any projection of biological organs into cultural reality and reversible scientific-technical projections of artificial man.

\section{References}

Bostrom, Nick. Superintelligence — Paths, Dangers, Strategies. United Kingdom: Oxford University Press. 2014.

Huning, Alois. "Ernst Kapp: Grundlinien einer Philosophie der Technik. Zur Entstehungsgeschichte der Cultur aus neuen Gesichtspunkten, 1877.” In Nachdenken über Technik. Die Klassiker der Technikphilosophie, edited by Christoph Hubig, Alois Huning and Günter Ropohl, 215-219. Berlin: Sigma, 2013.

Kale, Eduard. Uvod u znanost o kulturi (Introduction to the Science of Culture). Zagreb: Školska knjiga, 1982.

Kapp, Ernst Christian. Grundlinien einer Philosophie der Technik. Zur Entstehungsgeschichte der Cultur aus neuen Gesichtspunkten. Braunschweig: George Westermann, 1877.

McCorduck, Pamela. Machines Who Think: A Personal Inquiry into the History and Prospects of Artificial Intelligence. San Francisco: W. H. Freeman, 1979.

Turkle, Sherry. The Second Self. Computers and the Human Spirit. Twentieth anniversary edition, Cambridge-Massachussets-London: MIT Press, 2005. 
Sažetak

\title{
OD PROJEKCIJE LJUDSKIH ORGANA DO PROJEKCIJE UMJETNOG ČOVJEKA
}

\author{
Aktualni okviri filozofije tehnike
}

\section{IVANA GREGURIC, IVO DŽINIĆ}

U članku se na temelju teze njemačkoga teoretičara i pionira filozofije tehnike, Ernsta Kappa, o projekciji organa prilikom početnoga stvaranja oruđa, nastoji pokazati kako ta teza ima svoje implikacije još i danas, posebice u pogledu njezine reverzibilnosti. Naime, kada Kapp tvrdi da su sva oruđa nastala tako što je čovjek promatrao svoje organe i njihovu funkcionalnost, a da je među svim organima napose ruka oruđe svih oruđa, onda isto tako valja ustvrditi kako se je danas od projekcije organa prispjelo tome da je čovjek s aspekta tehnike dospio u poziciju da projicira tehnički sofisticirana oruđa za zamjenu ljudskih organa. Sve je prisutnija pojava zamjene ljudskih organa kao pripomoći i u mnogočemu olakšavanja čovjekova života, ali isto tako i svjesne i koordinirane kiborgizacije i robotike s ciljem pospješivanja i unaprjeđenja toga istoga života do razine izazivanja novoga stupnja njegove evolucije. Tako se stvaraju aktualni okviri filozofije tehnike, koja je uvelike započela sa naznačenom Kappovom tezom.

KLJUČNE RIJEČI: Ernst Kapp, organ, projekcija, filozofija, tehnika, kiborgizacija, transhumanizam, robotika, evolucija, posthumanizam

* Doc. dr. sc. Ivana Greguric, Fakultet hrvatskih studija Sveučilišta u Zagrebu, Borongajska cesta 83d, 10000 Zagreb, Hrvatska. E-adresa: igreguric@hrstud.hr ORCID iD: https://orcid.org/0000-0002-0148-2334

* * Izv. prof. dr. sc. Ivo Džinić, Fakultet hrvatskih studija Sveučilišta u Zagrebu, Borongajska cesta 83d, 10000 Zagreb, Hrvatska. E-adresa: idzinic@hrstud.hr 